\title{
A qualitative study about immigrant workers' perceptions of their working conditions in Spain
}

\author{
E 0 Ahonen, ${ }^{1}$ V Porthé, ${ }^{1}$ M L Vázquez, ${ }^{2}$ A M García, ${ }^{3}$ M J López-Jacob, ${ }^{4}$ C Ruiz-Frutos, ${ }^{5}$ \\ E Ronda-Pérez, ${ }^{6} \mathrm{~J}$ Benach, ${ }^{1} \mathrm{~F}$ G Benavides, ${ }^{1}$ for the ITSAL Project*
}

\begin{abstract}
${ }^{1}$ Department of Experimental and Health Sciences, Occupational Health Research Unit, Universitat Pompeu Fabra CIBER Epidemiology and Public Health, Barcelona, Spain

${ }^{2}$ Health Policy Research Unit, at Catalonia Hospitals' Consortium, Barcelona, Spain; ${ }^{3}$ Department of Preventive Medicine and Public Health, University of Valencia, and Trade Union Institute for Work, Environment and Health (ISTAS), Valencia Spain; ${ }^{4}$ Trade Union Institute for Work, Environment and Health (ISTAS), Madrid, Spain;

${ }^{5}$ Department of Biology and Public Health, University of Huelva, Huelva, Spain;

${ }^{6}$ Department of Public Health, University of Alicante, Alicante, Spain
\end{abstract}

Correspondence to:

Dr E 0 Ahonen, Division of Environmental and Occupational Health Sciences, School of Public Health, University of Illinois at Chicago, Chicago, IL, USA; ahonen@uic.edu

Accepted 14 April 2009 Published Online First 21 July 2009

\section{ABSTRACT \\ Background: Spain has recently become an inward migration country. Little is known about the occupational health of immigrant workers. This study aimed to explore the perceptions that immigrant workers in Spain had of their working conditions.}

Methods: Qualitative, exploratory, descriptive study. Criterion sampling. Data collected between September 2006 and May 2007 through semi-structured focus groups and individual interviews, with a topic guide. One hundred and fifty-eight immigrant workers $(90 \mathrm{men} / 68$ women) from Colombia $(n=21)$, Morocco $(n=39)$, subSaharan Africa $(n=29)$, Romania $(n=44)$ and Ecuador $(n=25)$, who were authorised (documented) or unauthorised (undocumented) residents in five medium to large cities in Spain.

Results: Participants described poor working conditions, low pay and health hazards. Perception of hazards appeared to be related to gender and job sector. Informants were highly segregated into jobs by sex, however, so this issue will need further exploration. Undocumented workers described poorer conditions than documented workers, which they attributed to their documentation status. Documented participants also felt vulnerable because of their immigrant status. Informants believed that deficient language skills, non-transferability of their education and training and, most of all, their immigrant status and economic need left them with little choice but to work under poor conditions.

Conclusions: The occupational health needs of immigrant workers must be addressed at the job level, while improving the enforcement of existing health and safety regulations. The roles that documentation status and economic need played in these informants' work experiences should be considered and how these may influence health outcomes.

Global human migration is currently on the rise. ${ }^{1-3}$ Migratory patterns in Spain have changed dramatically over the last several decades, transforming the country from one of internal movement and net emigration to one that is now considered an "inward migration" country. ${ }^{3}$ It is currently estimated that about 4482600 foreign migrants live in Spain, accounting for $10 \%$ of the total population. ${ }^{4}$ The vast majority of migrants will necessarily enter the job market in Spain.

Work is thought to influence health unequally within populations through: the type of work available geographically; gender and ethnicity; the skills, training and education that affect individual access to work; and job assignment. These factors in turn determine what one is exposed to in the workplace, as well as one's access to income and other benefits derived from work. ${ }^{6}$ Studies have suggested poor employment and working conditions in immigrant and some ethnic groups, as evidenced by poor perceived health, work-related health problems and injuries. ${ }^{3-14}$ Furthermore, data on occupational injury in Spain suggest an elevated risk in foreign workers. ${ }^{15-17}$ With the previous exception, available data on occupational health in immigrants to Spain are extremely limited..$^{18}$

This paper presents one aspect of the findings of a larger study conducted in five Spanish cities (the ITSAL Project, in its Spanish acronym). Its general objective is to study the working conditions and characteristics of precarious employment in immigrant workers and their relation to health. It does so through: analyses of available occupational injury data on foreign workers; qualitative interviews and focus groups with immigrant workers; and a questionnaire developed with the information obtained in the previous phases of the study. Each of the three substudies fed into the development of subsequent phases. Here, we present data obtained from the qualitative interviews and focus groups, aiming to analyse the perceptions that immigrant workers in Spain had of their working conditions.

\section{METHODS}

\section{Design and setting}

This qualitative, exploratory and descriptive study was carried out in five cities in Spain: Alicante, Barcelona, Huelva, Madrid and Valencia. An exploratory study design is appropriate when little previous information exists about the study subject, and the aim is to identify themes and composition within the subject and to generate hypotheses for future study. A descriptive study aims to document and describe a phenomenon and how it comes to pass in greater detail and depth. ${ }^{19}$ The study cities range in population from about 146000 in Huelva to over 3 million in Madrid, and all have sizeable immigrant populations. In Spain, individuals from Colombia, Morocco, sub-Saharan Africa, Romania and Ecuador make up 50.4\% of the documented foreign population. In the study cities, these same groups represent $44.2 \%$ of the total documented foreign population. ${ }^{20}$

\section{Participants}

This study employed criterion sampling, which uses a theoretical framework to guide the selection of participants according to established criteria. ${ }^{21}$ Selection criteria were: nationality other than 
Spanish, European Union-15 or other highly developed countries; at least 1 year's residence in Spain; both sexes, both documented and undocumented residency status; at least 3 months' total working experience in Spain; and belonging to a nationality group with substantial presence in Spain. Consequently, the participants selected were from Morocco, Romania, Colombia, sub-Saharan Africa and Ecuador. One nationality group was selected per city but, for reasons of confidentiality, that information is not presented here. At the time of the study, Romania had not been incorporated into the European Union.

Because of regional peculiarities in one study city, which determine the immigrant groups present at a given time, the initial sample design was modified there to include participants based on regional origin instead of one national origin. Participants hailed from various sub-Saharan African countries (Senegal, Nigeria, Zimbabwe, Mali, Ghana, Mauritania, Burkina Faso, Equatorial Guinea and Guinea Bissau). All sites sought maximum variation in terms of industry and age.

Lacking moderate fluency in Spanish was originally a cause for exclusion from the study. However, this criterion limited data collection in recently arrived undocumented individuals. Such individuals from Morocco and sub-Saharan Africa were then included in the study using interpreters. The interpreter for sub-Saharan participants was a male, Spanish member of the research team. The interpreter for the Moroccan participants was a male Moroccan cultural mediator employed by the researchers. Likewise, the required length of residence was relaxed in a few cases, allowing the participation of information-rich cases with less experience in Spain.

Researchers made contact with immigrant workers in a variety of ways: through organisations that worked with immigrants; the snowball method; posters and direct recruitment by the researchers in local stores, telephone centres, markets and neighbourhoods. Participant characteristics from the final sample of 158 workers can be found in tables 1 and 2 . In all, 99 participants were documented and 59 undocumented. Ninety were men and 68 were women. Eighty-three individuals participated in focus groups and 75 through individual interviews. The final sample size was determined by saturation of the discourse, or redundancy, ${ }^{21}$ meaning that collecting additional data does not yield new information relevant to the primary study questions.

\section{Data collection methods}

Data were collected between September 2006 and May 2007, through semi-structured individual interviews and focus groups, both using a topic guide. The guide explored migratory and working experience and health. Themes were based on published and grey literature, study interests and on a preliminary study with key informants in each study site. ${ }^{18}$

In focus groups, participants were segregated by sex and documentation status; in interviews, respondents were sought who fitted those four profiles. Sessions took place in community organisations and associations, cultural centres, meeting rooms in urban hotels and occasionally in the participants' workplaces or homes. They were conducted in Spanish by members of the research team. All data-gathering aided by interpreters was done through individual interviews. Consent to participate was obtained from every participant before participation. Informants received a modest economic stipend for their participation except in Alicante, where a limited research budget did not allow for stipends. All sessions were audio-recorded and transcribed in Spanish. Individual interviews lasted an average of 45 minutes and focus groups 90 minutes.

\section{Data analysis}

After review of the transcripts, texts were analysed by narrative content analysis, with support from the Atlas. $\mathrm{Ti}^{22}$ program. Data were stratified for analysis by documentation status and sex. A mixed generation of categories organised the sorting of data: the initial categories were derived from the interview guide and others were identified in the data as analysis continued. These categories were broadened or collapsed as analysis matured through constant comparison.

All analyses of data were done using the Spanish-language transcripts. As we began to draft this paper, relevant extracts from the data were chosen for use in the manuscript. At that point, the extracts used here were translated from Spanish to English by the first author, EA. In the case of those participants who spoke through interpreters, any extracts presented here are the interpretation of the original statement by the interpreter, subsequently translated into English. In cross-cultural and crosslanguage research, it is sometimes necessary to "convey meaning using words other than literally translated equivalents". ${ }^{23}$ As such, readers should be aware that the extracts used here are the translator's best attempt at a rigorous transmission of concept from source to target language rather than a word-for-word rendering of participant statements.

\section{Quality of data}

Several triangulation strategies were used to improve the quality of the data and conclusions. ${ }^{24}$ First, data were triangulated by source (the different immigrant groups studied

Table 1 Origin, length of time in Spain, sex and documentation status of immigrant participants in the qualitative ITSAL study, Spain 2008

\begin{tabular}{|c|c|c|c|c|c|c|}
\hline \multirow[b]{2}{*}{ Origin } & \multirow{2}{*}{$\begin{array}{l}\text { Age range } \\
\text { (years) }\end{array}$} & \multirow{2}{*}{$\begin{array}{l}\text { Range of time in } \\
\text { Spain (years) }\end{array}$} & \multirow[b]{2}{*}{ Sex } & \multicolumn{2}{|c|}{ Documentation status } & \multirow[b]{2}{*}{ Totals } \\
\hline & & & & Documented & Undocumented & \\
\hline \multirow[t]{2}{*}{ Colombia } & $24-60$ & $1.5-15$ & Male & 9 & 1 & 10 \\
\hline & & & Female & 10 & 1 & 11 \\
\hline \multirow[t]{2}{*}{ Morocco } & $20-52$ & $0.33-22$ & Male & 12 & 11 & 23 \\
\hline & & & Female & 12 & 4 & 16 \\
\hline \multirow[t]{2}{*}{ Sub-Saharan Africa } & $23-47$ & $0.5-17$ & Male & 12 & 14 & 26 \\
\hline & & & Female & 2 & 1 & 3 \\
\hline Romania & & & Female & 13 & 14 & 27 \\
\hline \multirow[t]{2}{*}{ Ecuador } & $18-55$ & $0.8-3$ & Male & 10 & 4 & 14 \\
\hline & & & Female & 7 & 4 & 11 \\
\hline Total range & $18-60$ & $0.33-22$ & Total participants & 99 & 59 & 158 \\
\hline
\end{tabular}


Table 2 Current industry and educational attainment of immigrant informants by sex and documentation status, ITSAL project, Spain 2008

\begin{tabular}{|c|c|c|c|c|}
\hline & \multicolumn{4}{|c|}{ Sex and documentation status } \\
\hline & \multicolumn{2}{|c|}{ Women $(n=68)$} & \multicolumn{2}{|l|}{ Men $(n=90)$} \\
\hline & $\begin{array}{l}\text { Documented } \\
(n=44) 28 \%\end{array}$ & $\begin{array}{l}\text { Undocumented } \\
(\mathrm{n}=24) \mathbf{1 5 \%}\end{array}$ & $\begin{array}{l}\text { Documented } \\
(n=55) 35 \%\end{array}$ & $\begin{array}{l}\text { Undocumented } \\
(\mathrm{n}=35) 22 \%\end{array}$ \\
\hline \multicolumn{5}{|l|}{$\begin{array}{l}\text { Educational } \\
\text { attainment }\end{array}$} \\
\hline Unknown & 2 & 2 & 4 & 2 \\
\hline $\begin{array}{l}\text { No formal } \\
\text { education }\end{array}$ & 2 & 1 & 0 & 0 \\
\hline $\begin{array}{l}\text { Primary } \\
\text { school }\end{array}$ & 7 & 3 & 8 & 10 \\
\hline $\begin{array}{l}\text { Secondary } \\
\text { school }\end{array}$ & 21 & 14 & 19 & 15 \\
\hline $\begin{array}{l}\text { University } \\
\text { studies }\end{array}$ & 12 & 4 & 24 & 8 \\
\hline Total & 44 & 24 & 55 & 35 \\
\hline \multicolumn{5}{|l|}{ Industry* } \\
\hline Agriculture & 2 & 1 & 7 & 12 \\
\hline Retail & 2 & 0 & 5 & 1 \\
\hline Construction & 0 & 0 & 15 & 6 \\
\hline $\begin{array}{l}\text { Household } \\
\text { service }\end{array}$ & 27 & 20 & 1 & 1 \\
\hline Education & 0 & 0 & 0 & 1 \\
\hline Manufacturing & 2 & 0 & 4 & 4 \\
\hline Other services & 6 & 2 & 14 & 1 \\
\hline $\begin{array}{l}\text { Accommodation } \\
\text { and food } \\
\text { services }\end{array}$ & 8 & 5 & 9 & 3 \\
\hline Unemployed & 1 & 0 & 3 & 6 \\
\hline $\begin{array}{l}\text { Multi-employed } \\
\text { individuals }\end{array}$ & 7 & 4 & 3 & 0 \\
\hline
\end{tabular}

* In this category, the number of jobs held in each category is listed, not the number of individuals; individuals are included in the industries of their various jobs in the case of multi-employment, meaning that the number of jobs listed is greater than the number of participants.

in each city). Multiple analysts reviewed the data and findings. Differences among analysts were addressed by discussion among analysts and by returning to the original data until a consensus was reached.

\section{RESULTS}

The final broad categories of analysis were working conditions, perception of hazards and influence of immigrant status. Here, data from those initial coding categories and emerging subcategories are structured into four narrative sections that summarise the main findings thematically. Extracts are labelled in the tables by documentation status, sex and data collection techniques (focus group (FG) or individual interview (II) participation). Ellipses signify that a portion of the original statement was omitted for clarity. Unless specifically noted, no differences were found by documentation status or sex.

\section{Overview of working conditions}

When asked about the conditions in their jobs, informants described them as "hard", "tough" and "heavy". One respondent said he did the same work as the "crane" did. Such descriptors were repeated regardless of documentation status and sex. Beyond those general qualifications, their perceptions of conditions at work were determined by their jobs. Informants routinely expressed the belief that these were the jobs available to them as immigrant workers, and many mentioned that this type of work was what Spaniards did not want or would not accept. Many were employed in small businesses. They believed that the conditions there were generally poorer and less regulated than in large businesses.

\section{Working conditions and hazards}

When invited to discuss their working conditions more specifically, informants frequently discussed them in terms of hazards, especially those in construction and agriculture. Many in these occupations felt that their jobs were very hazardous. They described safety deficiencies and the potential for injury due to falls, cuts, fallen objects, tools, sharp objects, poorly maintained equipment and carrying heavy weights. Some also mentioned exposure to dust and chemicals (table $3 a$ ).

Those in other industries described workplace conditions with somewhat less concern. Risks described by these participants were mostly associated with excessive noise, repetitive or awkward movement, standing for long periods of time, sharp objects and temperature conditions (table $3 b$ ).

While most participants at first had some difficulty discussing their working conditions, women often seemed more ambivalent, especially about potential hazards. When given examples of things they might have experienced at work, some women explained that, although they had ergonomic risks in their jobs, the same chemical hazards they had in their jobs were present in their unpaid work (table 3c).

Participants' foci were often on the potential for acute injuries, but some described poor conditions that would accumulate in their effects over time. These conditions were related to the heavy nature of their work and the physical stress this put on their bodies (table $3 \mathrm{~d}$ ).

Informants also described poor organisational conditions. They believed that their superiors and employers were more concerned with high production than with good working conditions. Many felt that the amount of work they were given to complete during their shifts was excessive, and others complained that their superiors pressured them to work faster. They worried about the potential dangers of this rushing for accidents, and many admitted that, although they knew of a "right" ergonomic method for performing their work, it was the first thing to go when they were in a hurry (table $3 e$ ).

Pay was frequently mentioned in tandem with discussion about working conditions. Informants believed that those conditions were not reflected in their wages. Most believed they were paid poorly, with reported salaries ranging from about 300 euros to 1200 euros a month. Some also mentioned the lack of alternative forms of recognition for such hard work, and felt that they were not valued as hard workers (table 3f).

Working time was another key organisational element discussed by participants. Almost all informants reported working long hours with few days off. Many undocumented informants also worked night or rotating shifts, and several respondents had more than one job out of economic necessity. Participants, especially those who worked in restaurants or bars, mentioned the difficulty of managing a known entry but not exit time, and many discussed the long time periods they spent commuting to and from work (table $3 \mathrm{~g}$ ).

The consequences of long working hours were that informants felt fatigued and overwhelmed. They had difficulty maintaining physical and mental energy, getting enough sleep, having time for unpaid work and leisure time. They believed this had health consequences (table $3 \mathrm{~h}$ ).

Certain organisational risks were especially present in the perceptions of the women. They discussed the monotony of their tasks, the interpersonal challenges of working in the homes and lives of others in household services, and the fact 
Table 3 Selected data related to perceived working conditions and hazards in immigrant informants in order of reference to them in the text, ITSAL project, Spain

a In the world of construction...it's where you always have to climb up high, setting up scaffolding, setting down planks...that is, there's always risk in construction activity, you know? (documented man, FG)

a In the fields... what can I tell you? It's really tough for a woman, really, really tough, lots of risk of, I don't know, getting stuck all over the place with branches, in your eyes, scratches, falling down... (undocumented woman, FG)

b I'm not in extreme situations where I could have an accident like that, I mean, you can cut yourself with a meat slicer, but those are things you have to learn as you work you have to be careful. (documented man, II)

c I think the risks involved in cleaning are, well, cleaning windows, high up and you have to lean way over, half your body is out in the air to clean the window, I see that as one of the risks, because the rest of it, no, it's like what one does at home... (undocumented woman, II)

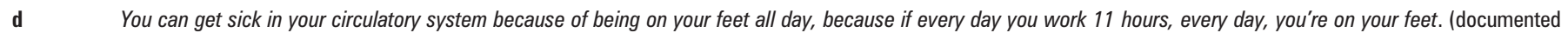
man, II)

e Even though I've seen in videos, like I said, because of being in a hurry, to get done, get home sooner, seeing all the work you've got accumulated, and...it seems like the time isn't going anywhere, you want to get done, and you do it badly... (undocumented woman, FG)

f Does that seem right to you, working 24 hours with a sick person? And then they pay you 600 euros (about \$850-900) at the end of the month? (documented woman, FG)

f You're not valued, you're not valued, but you're working hard. (documented man, FG)

g Here you never know the exact time (that work ends), because today, for example, we came in at 11:00 and we don't know what time we'll finish, because before we worked 11, 12, even 15 hours, depending on the amount of strawberries there were. (documented man, II)

g I worked all afternoon and all night almost, you know? I worked from 2 (pm) until almost 1 (am) ........as a waiter, between travel time and actual working time, it was almost 14 hours or something like that, I mean, it was terrible... (undocumented man, II)

h For example, imagine, working as a waitress like they do now, you don't work 8 hours but rather 16 or 14, imagine what it is to be on your feet after so much time, when tomorrow you have to go back and do the same shift, you're destroyed, you go home on all fours and the only thing you're dreaming of is your bed... you don't even have weekends lots of times. (documented woman, FG)

h Man, your health gets worse over time, so much work, so many hours, lots of night work. (documented man, FG)

i Obviously, we're all here doing different work than what we did at home, here we're all cleaning, caring for kids and old people. (documented woman, II)

that many were doing work that was very distinct from their education or training and their professional expectations (table $3 i)$.

\section{Formal hazard prevention}

Although some documented informants had had training in hazard prevention, few of the undocumented had received such training. In construction, an industry that gets significant attention for its risk and practices, many participants explained that the approach to safety was perfunctory. Informants frequently described being asked to sign a paper saying they had received safety training, personal protective equipment or both, whether or not they had. They described asking many times for improvement in safety standards or for better equipment that never arrived. Many documented and undocumented workers eventually bought their own personal protective equipment.

A less mentioned but not less relevant aspect of training was job training. Given that many participants worked in jobs that were not familiar to them, learning to do the job correctly and safely would be the first step to overcoming their lack of experience. It appeared that this training was largely informal and based on on-the-job observation of more experienced colleagues.

\section{"Papers", immigrant status and "no choice"}

Documentation and immigrant status and the economic importance of work came up with tremendous frequency among participants, in connection with almost any topic addressed. Participants felt that their situation was different from that of a native worker in similar work because of their immigrant status. They perceived heavier workloads, more dangerous and heavier tasks, longer hours and poorer pay. Some related these conditions to working in small businesses that they perceived to be less regulated (table 4a).

Undocumented workers directly related their poor working conditions to their lack of "papers", saying that without documentation they did not have access to work under better conditions, their employers took advantage of their status, and at the same time their jobs were the key to maintaining their precarious economic situations. They also believed that they were paid less than those who were in possession of their "papers". Furthermore, many undocumented workers believed that, if they proved themselves to be hard workers, their employers would offer them a contract, which they believed would help them achieve documented status (table 4b).

Although most intensely expressed among undocumented workers, this was not an issue relating only to them. Documented workers also felt that their status as immigrants affected their working conditions. They also mentioned being taken advantage of, but in more subtle circumstances (table 4c).

Informants felt that they had little room for asking for improvements. They were reluctant to complain to supervisors about these conditions, because they did not want to have "problems". For undocumented workers, this might mean the loss of their job and their income, or even deportation. For documented workers, who at least initially are dependent on a job to renew their documentation, the loss of a job could also mean the loss of documented status if they did not find another. In the precarious economic situation most informants were in, many with dependents in Spain or in their home country, the clear priority was to maintain their jobs and their incomes.

In addition, several other factors related to their immigrant status affected the amount of influence participants felt they had over their working conditions. Although these informants were average to well-educated, and many had prior vocational training, these qualifications were by and large not recognised in Spain. Furthermore, lack of language skills was an issue for many of the participants. The long hours they worked and their tight economic circumstances left little room for training or language study, and this limited their hopes of getting a job with better conditions, to have a "choice" about those conditions. Finally, membership in labour unions or other worker rights organisations was extremely low, meaning they had little formal support to turn to with regard to working conditions (table 4d). 
Table 4 Selected data related to "papers", immigrant status and "no choice" in immigrant worker participants, ITSAL project, Spain

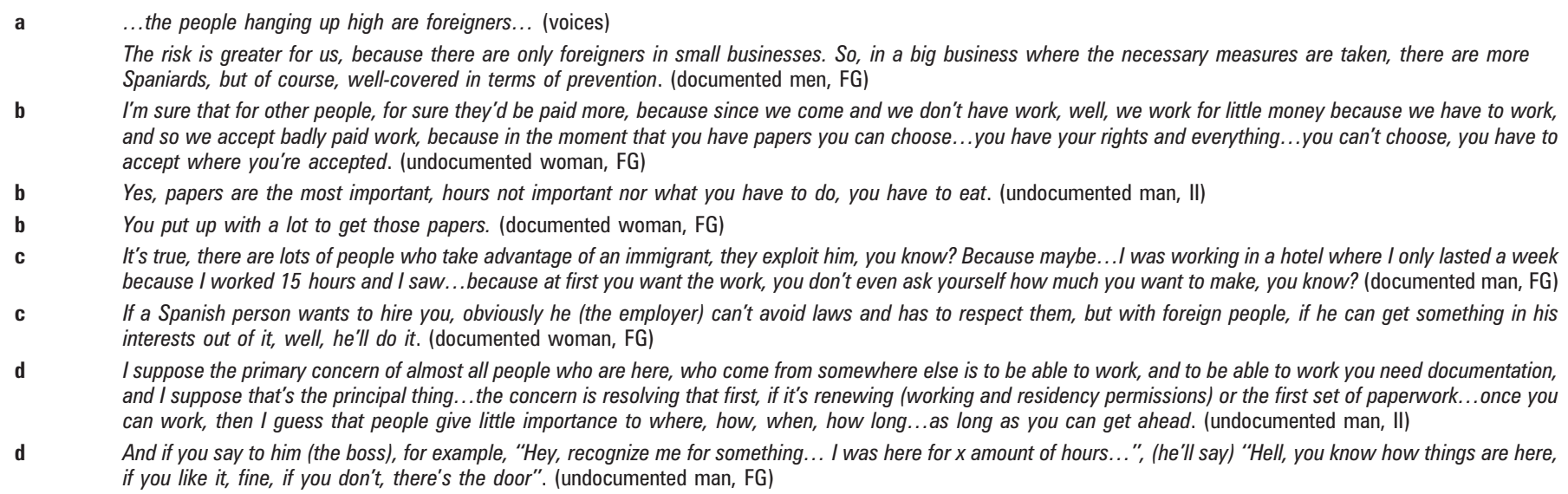

\section{DISCUSSION}

This study highlights the need to examine the occupational health needs of immigrant workers on a job-specific level, while considering the roles that occupational sex segregation, documentation status and economic necessity played in these informants' perceptions of their work experiences and how those factors may contribute to health outcomes.

In this study, individuals for whom Spanish was not a first language participated, along with native Spanish speakers. Researchers have pointed out that interpreters and translators play a part in cross-language research beyond the neutral transmission of information from research subject to researcher, ${ }^{23}{ }^{25-27}$ and that as such the reflexivity that is central to qualitative enquiry should be extended to consideration of the role they play in constructing meaning in research. ${ }^{25} 27$ Temple ${ }^{26}$ advocates the use of "intellectual autobiography" as a tool for aiding such reflexivity. Indeed, here, EA was one of the data collectors, analysts and a translator. She is a native English speaker with Spanish academic training and several years' professional experience both in the United States and in Spain. Her aim in translating the extracts was creating clarity of concepts as she and the other researchers understood them for an English-language audience. We have made efforts to confirm and clarify comments where that was necessary, to "elucidate the experience that is implicated by the subjects". ${ }^{28}$ This was done through consultation with the interpreters used in the interviews, by returning to interviewees when necessary and by discussion among researchers. While it presents challenges, involvement of translators and interpreters in the research study can be seen to enrich the research process. ${ }^{29}$ Even so, it is possible that some detail from people with weaker Spanish skills may have been lost, and certainly EA's translation represents only one of the possible renderings of the data into English.

This sample was average to well-educated (table 2). Two-thirds ( $n=117$ ) of the sample had completed secondary school or higher level studies, and many were overqualified for the work they were doing in Spain. These tendencies have been noted elsewhere, and have been considered as evidence that migrants may be being directed into unskilled jobs with low wages, instability and potentially negative health and safety consequences. ${ }^{3}$

The analysis presented shows that informants perceived health hazards in their working conditions. Their descriptions of long working hours and unfavourable conditions are similar to those described at a European level. ${ }^{3} 30$ This suggests that immigrant workers continue to be a vulnerable population in the workforce. Many women seemed to perceive structural and environmental risks less acutely than men. This probably indicates a relationship to occupation. In this sample, workers were heavily segregated by sex into certain occupations, making it difficult to separate one from the other. Furthermore, the majority of women in the sample worked in household services, which left them performing similar tasks in paid employment as well as at home. Less perception of risk, if it was such, may have been simple pragmatism.

Putting up with poor conditions was not a matter of ignorance on the part of participants. However, many seemed to view poor conditions and risk as inherent parts of work, at least in their status as immigrants. Many informants also felt that their superiors and employers were not concerned with their working conditions. This finding is especially significant when taken in combination with the limited preventive measures described, participants' economic pressures and their perception of limited possibilities for obtaining improved working conditions. Remarkably similar concerns about safety, production and job insecurity have been reported by Lipscomb and colleagues ${ }^{31}$ in a group of mostly white male union carpenters in the United States, a population that, by nature of being organised, should enjoy certain official protections. Given those results, they emphasise the need to empower workers in ways that go beyond training. If the immigrant workers in our sample felt that the risks outweighed the benefits of individually advocating for better conditions, and they lacked the formal structure for such advocacy, possibilities for exploitation are high.

The working conditions described here have implications for health inequalities. As Lipscomb et al point out, ${ }^{5}$ why people work where they do and under what conditions is not only influenced by personal characteristics, but also by larger forces such as the job market, institutional discrimination and neighbourhood segregation. In this group of workers, immigrant status may well be influencing the jobs and working conditions available to them. Such observations point to the need to look beyond the hazards associated with a specific kind of work to include the social and documentation reality of immigrant workers as potential sources of occupational health inequalities. For this group of workers, working conditions and documentation situation were directly related, which may be especially important given that many of the workers were in informal work arrangements. 


\section{What is already known on this subject}

- Work is thought to influence health unequally depending on conditions.

- Studies have suggested poor employment and working conditions for immigrant workers.

\section{What this study adds}

- Workers reported poor job-specific working conditions that they believed negatively affected their health, although they viewed a certain component of risk as inherent to working life in their condition as immigrants.

- They believed they had little power to influence their working conditions. This lack of power was related to immigrant status, fear of negative repercussions and economic necessity.

- In a Spanish and European context, efforts should be made to ensure that newly arrived individuals have the chance to integrate through good-quality jobs that will not negatively influence their health.

\section{Implications for policy and research}

Several issues relating to policy and research come to light. First, better enforcement of regulations regarding working hour ${ }^{32}$ and pay would benefit workers such as those who informed this study, most of whom regularly worked hours considered long ${ }^{33}$ and for whom collective pay scale agreements seemed to have little influence. The minimum wage established for the year 2008 is 600 euros/month. ${ }^{34}$ Although many participants reported salaries that were equal to or above that amount, they also emphasised that they regularly worked long hours and were not compensated for them. Some participants were also paid substantially less. Additionally, it was clear in this study that better enforcement is especially necessary in small and medium-sized businesses.

The presence of immigrant women in household services, an incredibly unregulated industry, deserves attention from research, intervention and policy-makers. For example, laws regarding the prevention of occupational hazards do not currently apply to this group of workers, and formal job contracts are not required. ${ }^{35}{ }^{36}$ This lack of legal protection, and the pervasive invisibility of household workers, leaves them vulnerable to conditions that may be negative to their health and well-being.

Future study of occupational health in immigrants should explicitly address documentation issues. Undocumented workers related regularised administrative status with an improvement in working conditions, but documented workers also felt that they occupied vulnerable positions. Initially, maintaining a job and contributions to the social security system are necessary to maintain a work permit in Spain. Working permits linked to residency permission (not dependent on a certain job) with longer duration of the permit would also aid in avoiding exploitation. Fear of negative consequences such as job, income or documentation loss or deportation may leave workers unwilling to demand better working conditions. Allowing undocumented immigrants to regularise their statu ${ }^{37}$ is a step towards addressing this problem, but is not enough to guarantee the rights of those workers. Recent efforts on the part of labour unions to reach out to immigrant workers ${ }^{3}$ should be encouraged, as should consideration of their unique needs within the union context.

Finally, as one editoria ${ }^{38}$ suggests, occupational safety and health institutions and researchers should continue to evaluate the potential contributions of working conditions and hazards to health inequalities. Spain is in a unique position to pursue improvements in the enforcement of safe working conditions and fair treatment for immigrant workers, which will help to limit negative impacts on their health. But we must make directed efforts to ensure that newly arrived individuals have the chance to integrate through a good-quality job.

Acknowledgements: The authors thank all participants in the study for sharing their time and experiences. We are also grateful for the comments of peer reviewers that helped to improve this manuscript.

Funding: The study was funded by grants from Fondo de Investigaciones Sanitarias (Spanish Fund for Health Research), grant numbers FIS PI050497, PI052334, PI061701 and PI052202, and also by CIBER Epidemiology and Public Health Spain, Consejería de Empresa, Universidad y Ciencia de la Generalitat Valenciana, grant number AE/07/068, Valencian Regional Government, Ministry of Business, University and Science and ARAl-AGAUR (Agency for the Management of University and Research Grants), grant number 2006 ARAI 00020

*Other researchers in the ITSAL Project: A A Agudelo-Suárez (Faculty of Dentistry, University of Antioquia, Medellín, Colombia, and Area of Preventive Medicine and Public Health, University of Alicante, Alicante, Spain), R Castiñeira (University of Huelva, Huelva, Spain), A Garí (Trade Union Institute for Work, Environment and Health, ISTAS), D Gil (University of Alicante, Alicante, Spain), G Paramio and I Velásquez (University of Huelva, Huelva, Spain).

Competing interests: None.

Provenance and peer review: Not commissioned; externally peer reviewed.

\section{REFERENCES}

1. Castles S, Miller MJ. The age of migration: international population movements in the modern world. London: Macmillan Press, 1998:5-6.

2. Ehrenreich B, Russell Hochschild A. Introduction. In: Ehrenreich B, Russell Hochschild A, eds. Global woman: nannies, maids, and sex workers in the new economy. New York: Henry Holt and Co., 2002:1-13.

3. European Foundation for the Improvement of Living and Working Conditions Employment and working conditions of migrant workers 2007. http://www. eurofound.europa.eu/ewco/studies/tn0701038s/ (accessed Nov 2007).

4. Spanish National Statistics Institute (INE). Municipal register of inhabitants. Advance 1/1/2007. http://www.ine.es/jaxi/menu.do?type=pcaxis\&path= $\% 2 \mathrm{Ft} 20 \% 2 \mathrm{Fe} 260 \% 2 \mathrm{Fa} 2007 \% 2 \mathrm{~F} q \mathrm{fil}=$ = pcaxis\&N $=\mathscr{G L}=0$ (accessed Jan 2008)

5. Lipscomb HJ, Loomis D, McDonald MA, et al. A conceptual model of work and health disparities in the United States. Int J Health Services 2006;36:25-50.

6. Benach J, Muntaner C, Santana V, chairs. Employment conditions and health inequalities. Geneva: Draft report to the WHO, Commission on Social Determinants of Health, Employment Conditions Knowledge Network 2007. http://www.emconet.org/ EMCONETREPORT.pdf (accessed Nov 2008).

7. Azaroff LS, Levenstein C, Wegman DH. The occupational health of Southeast Asians in Lowell: a descriptive study. Int J Occup Environ Health 2004;10:47-54.

8. Burgel BJ, Lashuay N, Israel L, et al. Garment workers in California: health outcomes of the Asian immigrant women workers clinic. AAOHN J 2004;52:465-75.

9. Malievskaya E, Rosenberg N, Markowitz S. Assessing the health of immigrant workers near Ground Zero: preliminary results of the World Trade Center Day Laborer Medical Monitoring Project. Am J Ind Med 2002;42:548-9.

10. Loh K, Richardson S. Foreign-born workers: trends in fatal occupational injuries, 1996-2001. Mon Labor Rev 2004;June:42-53.

11. Richardson DB, Loomis D, Bena J, et al. Fatal occupational injury rates in southern and non-southern states, by race and Hispanic ethnicity. Am J Public Health 2004;94:1756-61.

12. Dong $\mathbf{X}$, Platner JW. Occupational fatalities of Hispanic construction workers from 1992-2000. Am J Ind Med 2004;45:45-54.

13. Carangan $\mathbf{M}$, Tham KY. Work-related injury sustained by foreign workers in Singapore. Ann Acad Med Sing 2004;33:209-13.

14. Pransky G, Moshenberg D, Benjamin K, et al. Occupational risks and injuries in nonagricultural immigrant Latino workers. Am J Ind Med 2002;42:117-23.

15. López-Jacob MJ, Ahonen EQ, García AM, et al. Lesiones por accidente de trabajo en trabajadores extranjeros por actividad económica y Comunidad Autónoma (España, 2005) [Occupational injury in foreign workers by economic activity and autonomous community (Spain, 2005)]. Rev Esp Salud Pública 2008;82:179-87. 
16. Benavides FG, Ahonen EQ, Bosch C. Riesgo de lesión por accidente de trabajo en trabajadores extranjeros, España 2003 y 2004 [Risk of occupational injury in foreign workers, Spain 2003 and 2004]. Gac Sanit 2008;22:44-7.

17. Ahonen E0, Benavides FG. Risk of fatal and non-fatal occupational injury in foreign workers in Spain. J Epidemiol Community Health 2006;60:424-6.

18. García AM, López-Jacob MJ, Agudelo-Suárez AA, et al. Condiciones de trabajo y salud en inmigrantes (proyecto ITSAL): entrevistas a informantes clave [Working conditions and health in immigrants (ITSAL Project): key informant interviews]. Gaceta Sanit 2009;23:91-7.

19. Marshall C, Rossman G. Designing qualitative research. London: Sage Publications, 1990

20. State Secretary for Immigration and Emigration. Foreigners with current card or residency permission as of 31 December, 2007. Madrid: Ministry of Labour and Social Affairs 2007. http://extranjeros.mtas.es (accessed Jan 2008).

21. Patton M0. Qualitative evaluation and research methods, 2nd edn. Newbury Park: Sage Publications, 1990

22. Atlas Ti. The knowledge workbench, version 4.1. Berlin: Scientific Software Development, 1997

23. Temple B. Watch your tongue: issues in translation and cross-cultural research Sociology 1997;31:607-18.

24. Miles MB, Huberman AM. Qualitative data analysis: an extended sourcebook. 2nd edn. Thousand Oaks: Sage Publications, 1994

25. Temple B, Edwards R. Interpreters/translators and cross-language research: reflexivity and border crossings. IJOM 2002;1:article 1. http://www.ualberta.ca/ ijqm/ (accessed Dec 2008).

26. Temple B. Crossed wires: interpreters, translators, and bilingual workers in crosslanguage research. Qual Health Res 2002;12:844-54.

27. Temple B, Young A. Qualitative research and translation dilemmas. Qual Res 2004;4:161-78.

28. Altheide DL, Johnson JM. Criteria for assessing interpretive validity in qualitative research. In: Denzin NK, Lincoln YS, eds. Handbook of qualitative research. Thousand Oaks: Sage Publications, 1994:491.

29. Larkin PJ, Dierckx de Casterlé B, Schotsmans P. Multilingual translation issues in qualitative research: reflections on a metaphorical process. Qual Health Res 2007:17:468-76.

30. McKay S, Craw M, Chopra D. Migrant workers in England and Wales: an assessment of migrant worker health and safety risks. London: Health \& Safety
Executive Books, Working Lives Research Institute, London Metropolitan University, 2006. http://www.hse.gov.uk/research/rrhtm/rr502.htm (accessed Feb 2008).

31. Lipscomb HJ, Dale AM, Kaskutas V, et al. Challenges in residential fall prevention: insight from apprentice carpenters. Am J Ind Med 2008;51 60-8.

32. Workers' Statute. Madrid: Ministry of Labour and Immigration (MTIN, formerly MTAS). 2006. http://www.mtin.es/es/publica/estatuto06/estatuto.htm (accessed Jun 2009)

33. European Foundation for the Improvement of Living and Working Conditions Fourth European Working Conditions Survey. European Foundation for the Improvement of Living and Working Conditions, 2007. http://www.eurofound.europa. eu/ewco/surveys/index.htm (accessed Nov 2007).

34. BOE de $\mathbf{2 9}$ de diciembre de 2007, núm. 312. Ministerio de trabajo e immigracion, Real Decreto 1763/07, de 28 de diciembre. Fija el salario mínimo interprofesional para 2008 [Official State Bulletin, 29 December 2007, no. 312. Ministry of Labour and Immigration, Royal Decree 1763/07, of 28 December. Sets minimum interprofessional wage for 2008]. http://www.mtin.es/itss/web/Atencion_al_Ciudadano/ Normativa y Documentacion/Normativa/Normativa/pdfs/ RD 1763 07 SMl 20071229.pdf (accessed Jun 2009)

35. LE $\bar{Y} \mathbf{3 1} / \mathbf{1 9} 95$, de $\overline{\mathbf{8}}$ de noviembre de prevención de riesgos laborales. BOE no. 269, de 10 de noviembre. [LAW 31/1995, from November 8 of Prevention of Occupational Hazards. Official State Bulletin no. 269, November 10]. http://info.mtin. es/itss/web/Atencion al Ciudadano/Normativa y Documentation/Normativa/ Normativa/pdfs/LEY $\overline{3} 1 \overline{1} 1995$ PREVENCION DE $\bar{R}$ RIESGOS LABORALES.pdf (accessed Jun 2009).

36. Pla Julián I, Banyuls Llopis J, Cano Cano E, et al. Informalidad del empleo y precariedad laboral de las empleadas del hogar [Employment informality and employment precariousness in female household service workers]. Madrid: Ministry of Equality, Secretary General for Equality Policy, Women's Institute, 2004. http://www.migualdad.es/mujer/mujeres/estud_inves/658.pdf laccessed Jan 2009).

37. Real Decreto 2393/2004 de 30 de diciembre, Ley orgánica 4/2000 de 11 de enero, sobre derechos y libertades de los extranjeros en España (BOE number 6-323) [Royal Decree 2393/2004 of December 30, Law 4/2000 of January 11, on rights and liberties of foreign individuals in Spain (Official State Bulletin no. 6-323)].

38. Costa G, D'errico A. Inequalities in health: do occupational health risks matter? Eur J Public Health 2006:16:340. 